\title{
Protein production by cultures established from Day-14-16 sheep and pig conceptuses
}

\author{
J. D. Godkin, F. W. Bazer* and R. M. Roberts $\dagger$ \\ Department of Animal Science, University of Tennessee, Knoxville, Tennessee 37901-1071; and \\ *Department of Animal Science and $†$ Department of Biochemistry and Molecular Biology, \\ University of Florida, Gainesville, FL 32611 U.S.A.
}

\begin{abstract}
Summary. Primary cell cultures were established from cells derived from dissociated Day-14 and -16 sheep and pig blastocysts. The appearance of cells in culture from both species was similar. Cultures contained a variety of cells with distinct morphologies, some were small and compact and formed clumps and multiple layers while others were large, flat and formed a monolayer. Within $4 \mathrm{~h}$ of culturing small floating fluid-filled spheres of cells were observed in the medium; some of these increased in size to $>1 \mathrm{~cm}$ diameter over 1-2 weeks. In addition, fluid-filled domes of cells arose from the underlying monolayer. Contractile cells became evident after about 8 days and some became organized into large patches of contracting tissue. Two-dimensional polyacrylamide gel electrophoresis and fluorography were performed on proteins released into the medium by confluent monolayers, floating spheres and floating cells that failed to attach during the first $24 \mathrm{~h}$. All cultures produced as major products proteins with electrophoretic mobilities identical to certain fetal plasma proteins. In general, cultures did not produce proteins characteristic of short-term cultures of whole conceptuses harvested at Days 14-16. In cultures established from sheep blastocysts only the cells that failed to attach produced ovine trophoblast protein-1, a major polypeptide produced by the trophectoderm of the sheep conceptus between Days 13 and 21 of pregnancy.
\end{abstract}

\section{Introduction}

The proteins produced by the extra-embryonic membranes of the developing conceptus may have important functions in the metabolic, endocrinological and immunological adjustments that occur during pregnancy. The proteins synthesized in vitro by sheep and pig blastocysts during the pre-, peri- and post-attachment periods have been described and some of the proteins that were released into the culture medium have been purified and characterized (Godkin, Bazer, Moffatt, Sessions \& Roberts, 1982a; Godkin, Bazer, Geisert, Lewis \& Roberts, 1982b; Masters et al., 1983). However, the yield of such proteins is relatively small and their preparation is time consuming and expensive. The successful cell and organ culture of placental tissues which secrete hormones (Allen \& Moor, 1972; Aggarwal, Farmer, Papkoff, Stewart \& Allen, 1980; Kohdr \& Siler-Kohdr, 1980; Stevens, Mallon \& Nathanielsz, 1980; Ruddon et al., 1981) encouraged us to attempt to establish cell cultures from pig and sheep blastocyst tissue, with the hope that these cultures might supply a continuous source of secretory products for purification.

\section{Materials and Methods}

\section{Materials}

Fetal calf serum and trypsin solution were purchased from GIBCO Laboratories, Grand Island, New York. All other materials employed, including tissue culture supplies, radiochemicals, 
surgical supplies and electrophoresis materials and equipment were supplied by vendors noted by Godkin et al. (1982a, b).

\section{Animals}

Crossbred gilts, primarily of Duroc, Hampshire and Yorkshire breeding, and crossbred ewes primarily of Rambouillet breeding were observed for oestrus daily and inseminated by natural service as described previously (Godkin et al., 1982a, b). The day of the onset of oestrus was designated Day 0. Gilts were hysterectomized under aseptic conditions on Days 14 and 16 of pregnancy. Uteri were transferred to a laminar flow hood; conceptuses were flushed from the uterine horns with sterile medium and collected into culture dishes. Ewes selected as embryo donors were mated to 2 intact rams at oestrus. Some animals were superovulated by intramuscular injection of 500-1000 i.u. PMSG on Day 12 of the oestrous cycle and mated at the next oestrus. Blastocysts were collected as previously described (Godkin et al., 1982a) and transported to a sterile laminar flow hood.

\section{Medium preparation}

Eagle's minimum essential medium (MEM) containing phenol red $(10 \mu \mathrm{g} / \mathrm{ml})$ as an indicator was prepared as previously described (Basha, Bazer \& Roberts, 1979; Godkin et al., 1982a, b). The concentration of L-leucine was reduced to one-tenth its normal level when radiolabelled L-leucine was added as a tracer. MEM was supplemented with penicillin (200 units/ml), streptomycin (200 $\mu \mathrm{g} / \mathrm{ml})$, fungizone $(0.5 \mu \mathrm{g} / \mathrm{ml}), 0.2$ units insulin $/ \mathrm{ml}, 1 \%(\mathrm{v} / \mathrm{v})$ non-essential amino acids and $15 \%$ bovine fetal calf serum (MEM-FCS).

\section{Tissue culture}

Day-14 or -16 pig and sheep conceptuses were flushed from uteri as above and minced by crossing two scapel blades (No. 10) and cutting across the tissue. The resulting tissue pieces were incubated for $20-40 \mathrm{~min}$ in 5-10 ml trypsin (0.25\%) in Hank's Basic Salt Solution (HBSS) at $37^{\circ} \mathrm{C}$ in a rotating water bath. After incubation the suspension was diluted with $15 \mathrm{ml}$ MEM-FCS and the tissue pieces were mechanically dissociated into single cells and small clumps of cells by gently drawing the tissue clumps back and forth through a sterile, siliconized, flame-polished Pasteur pipette. The cells and small tissue fragments were centrifuged $(100 \mathrm{~g}, 5 \mathrm{~min})$, resuspended in MEMFCS, seeded at very high densities in T-75 culture flasks (equivalent to $1-3$ blastocysts/flask) and placed in a $37^{\circ} \mathrm{C}$ incubator with a gaseous atmosphere of $5 \% \mathrm{CO}_{2}: 95 \%$ air.

\section{Incubation of cultured cells for analysis of protein synthesis}

Cells derived from pig blastocysts. Large, free-floating, fluid-filled spheres which developed during tissue culture were pooled (4-7 spheres), 7-14 days after original seeding, washed three times in HBSS and transferred to a $35-\mathrm{mm}$ tissue-culture dish and incubated in $3 \mathrm{ml} \mathrm{MEM}$ containing $50 \mu \mathrm{Ci} \mathrm{L}-\left[{ }^{3} \mathrm{H}\right]$ leucine at $37^{\circ} \mathrm{C}$ on a rocking platform $(6 \mathrm{cycles} / \mathrm{min})$ in a gaseous atmosphere of $50 \% \mathrm{O}_{2}: 45 \% \mathrm{~N}_{2}: 5 \% \mathrm{CO}_{2}$ for $24 \mathrm{~h}$. At the end of the incubation period the medium was withdrawn and centrifuged $(12500 \mathrm{~g}, 20 \mathrm{~min})$. The spheres were transferred to centrifuge tubes, lanced and centrifuged $(12500 \mathrm{~g}, 20 \mathrm{~min})$. Tissue and fluid from inside the spheres were thus separated and processed separately.

Cells derived from sheep blastocysts. Dissociated sheep blastocyst cells were seeded at such a density that within $24 \mathrm{~h}$ a confluent cell layer was formed. The cells that did not attach to the plastic by $24 \mathrm{~h}$ were removed, washed three times in HBSS, transferred to a $35-\mathrm{mm}$ tissue-culture dish and incubated for $24 \mathrm{~h}$ in $3 \mathrm{ml} \mathrm{MEM}$ containing $50 \mu \mathrm{Ci} \mathrm{L}-\left[{ }^{3} \mathrm{H}\right]$ leucine. The confluent cell layer (cells that 
attached to plastic) was washed three times in HBSS and incubated for $24 \mathrm{~h}$ in $10 \mathrm{ml}$ MEM containing $100 \mu \mathrm{Ci} L-\left[{ }^{3} \mathrm{H}\right]$ leucine. Large free-floating spheres were harvested 7-14 days after original seeding and incubated under the same conditions as those described for spheres derived from pig blastocysts.

Preparation of samples for electrophoresis. Medium from all incubations was dialysed extensively against $10 \mathrm{~mm}$-Tris- $\mathrm{HCl}(\mathrm{pH} 8.2)$ to remove low molecular weight compounds, e.g. salts and unincorporated radiolabelled precursors and freeze dried. The dried material was dissolved in 5 mM- $\mathrm{K}_{2} \mathrm{CO}_{3}$ containing $9.4 \mathrm{M}$-urea, $2 \%(\mathrm{v} / \mathrm{v})$ Nonidet $\mathrm{P}-40$ and $0.5 \%$ dithiothreitol and analysed by two-dimensional polyacrylamide electrophoresis (PAGE). Tissues were suspended in $0.5 \mathrm{ml} 5 \mathrm{mM}$ $\mathrm{K}_{2} \mathrm{CO}_{3}, 9 \cdot 4 \mathrm{M}$-urea and sonicated $(4 \times 15 \mathrm{sec})$ in an ice bath using a Bromwell Biosonic at $20-40 \%$ probe intensity. The sonicated material was made to $2 \%(\mathrm{w} / \mathrm{v})$ Nonidet $\mathrm{P}-40$ and $0.5 \%$ dithiothreitol and centrifuged at $20000 \mathrm{~g}$ for $20 \mathrm{~min}$. The clear supernatant fraction was used for electrophoretic analysis of polypeptides.

Two-dimensional PAGE. Proteins released into the medium by cultures of sheep and pig conceptuses were analysed by a modification of the method of O'Farrell (1975) as described by Horst \& Roberts (1979) and used by Godkin et al. (1982a, b). After electrophoresis, slab gels were impregnated with sodium salicylate (1 M; $30 \mathrm{~min}$ ) (Chamberlain, 1979), dried and fluorographs were prepared (Laskey \& Mills, 1975) from Kodak XRP-1 X-ray film.

\section{Results}

\section{Cell cultures}

The morphological appearances of cells cultured from dissociated pig and sheep blastocysts were similar, therefore the following description applies to cells derived from both species. Within $4 \mathrm{~h}$ of culturing, many cells had attached to the culture dishes. However, many cells failed to attach within $24 \mathrm{~h}$. Within a single culture dish, cells with markedly different appearances were observed. Some, which formed clumps and multilayers, were generally small and compact while others were large and flat, formed monolayers and ceased dividing after 2-4 days. These then became overgrown by the more compact cells.

Within 2-4 days and times thereafter, many patches of cells appeared to become organized into differentiated structures. Contractile cells, for example, became evident and some of these developed into large patches of contracting tissue after about 8 days. One such colony derived from pig blastocysts continued to 'beat' for more than 60 days at a frequency of about $70-80$ 'beats' per $\min$ at $37^{\circ} \mathrm{C}$. Fluid-filled domes of cells also arose from regions of confluent monolayer. Additionally, after about 2 weeks in culture, small spheres $(\sim 1 \mathrm{~mm}$ diam.) formed from the monolayer pinched off and became free floating. These did not develop into large spheres (see below) and biochemical analysis was not performed on them.

Many of the dissociated cells and small clumps of cells did not attach to the plastic dish. Within $4 \mathrm{~h}$, fluid-filled, floating spheres ( $<1 \mathrm{~mm} \mathrm{diam}$.) were observed. It could not be determined whether these spheres formed from reaggregation of dissociated cells or fluid-induced cavitation of clumps of cells. Once formed, some of the spheres increased in size to a diameter of $>1 \mathrm{~cm}$ (Pl. 2, Fig. 5). This process took about 2 weeks. The larger translucent spheres developed what appeared to be a system of blood capillaries. Sometimes spheres attached to the dish and a monolayer of cells grew out around the regions of attachment.

\section{Analysis of protein synthesized by cultures derived from sheep blastocysts}

Two-dimensional PAGE analysis and fluorography were performed on the polypeptide products released into the culture medium by confluent cell layers established from dissociated blastocysts (PI. 1, Fig. 1), from large floating spheres established for 7-14 Days (PI. 1, Fig. 2) and 
from floating cells that failed to attach after $24 \mathrm{~h}$ from initial plating of dispersed blastocyst cells (Pl. 1, Fig. 3). Only in the latter preparation did we detect ovine trophoblast protein-1 which we have previously shown to be the major product secreted into culture medium by whole Day-13-21 sheep blastocysts (Godkin et al., 1982a; Godkin, Bazar \& Roberts, 1984). The polypeptides (numbered 1-4) produced in major amounts by all the preparations were identical in mobility to polypeptides found in fetal sheep plasma (Pl. 1, Fig. 4).

\section{Analysis of polypeptides produced by cultures derived from pig blastocysts}

The results of these analyses were essentially similar to those for the sheep. Characteristic blastocyst secretory products (Godkin et al., 1982b) were not formed by the cultured cells and the main products released appeared to be plasma proteins. Results obtained with the large floating spheres are illustrated in Pl. 2, Figs 6 and 7. Polypeptides numbered 1-4 have been tentatively identified on the basis of comigration with standards (1 and 2) or electrophoresis position (Anderson \& Anderson, 1977) as 1, transferrin; 2, $\alpha$-fetoprotein; 3, $\alpha_{1}$-antitrypsin; and 4, fibrinogen $\beta$-chain. With the exception of albumin (arrow) nearly all of the Coomassie blue-stained proteins (Pl. 2, Fig. 6) are also present on the fluorograph (Pl. 2, Fig. 7). Pl. 2, Fig. 8 is a protein map of Day 60 fetal pig plasma for comparison. Nearly all of the proteins synthesized by the spheres were present in fetal serum.

The material accumulated within the spheres was also analysed. These proteins, when analysed by two-dimensional PAGE, were identical to those released into the culture medium. In addition, results obtained from confluent cell cultures from pig blastocysts were essentially the same as those from fluid-filled spheres. Results from spheres harvested 7 and 14 days after initial seeding were similar.

\section{Discussion}

Cells derived from sheep and pig blastocysts were introduced into primary cultures and maintained for several months. A variety of cell types became evident and diverse patterns of cellular arrangements developed. Others have described the attachment and outgrowth cells from blastocysts of the mouse (Mintz, 1964; Cole \& Paul, 1965; Gwatkin, 1966), rabbit (Edwards, 1964), rat (Owens \& Blandau, 1971), guinea-pig (Blandau, 1971) and pig (Shaffer \& Wright, 1978). Hsu $(1971,1972,1973)$ demonstrated in-vitro development of the mouse embryo. As in the study of Shaffer \& Wright (1978), the large, flat cells in our cultures ceased to divide after a few days, although they remained attached for several weeks. Cole \& Paul (1965) were first to report the longterm culture of mammalian blastocyst cells. They successfully cultured cells from disaggregated rabbit blastocysts for more than 200 generations. The cell types obtained were reported to be both fibroblastic and epithelioid. The first long-term culture of mouse blastocysts was reported by Sherman (1975), who observed that cells that migrated from the inner cell mass of mouse blastocyst cultures proliferated as a monolayer, contained a variety of cell types, and eventually overgrew trophoblast cells. We also observed a rapidly growing monolayer of compact cells which overgrew the thin flat cells in the sheep- and pig-derived blastocyst cultures. Hogan \& Tilly (1977) reported that ectoderm, isolated from a single mouse blastocyst and cultured on fibroblast feeder cells, attached to the substratum and differentiated into various tissues including skin, nerve, beating muscle, cartilage and fibroblasts. We too observed that a diverse array of cells and cell structures developed from the compact cells, including patches of cells that contracted rhythmically. We used dissociated Day-14 and -16 pig blastocysts to establish these cultures. In the pig blastocyst the fetal heart begins to beat about 16-18 days after conception (Patten, 1931). It seems likely, therefore, that fetal myocardial cells (or cells destined to become such) are capable of organizing and differentiating in culture to form the observed contracting structures. Hsu $(1971,1972,1973)$ observed in-vitro differentiation of mouse blastocysts to a form which included a beating heart. To 


\section{PLATE 1}
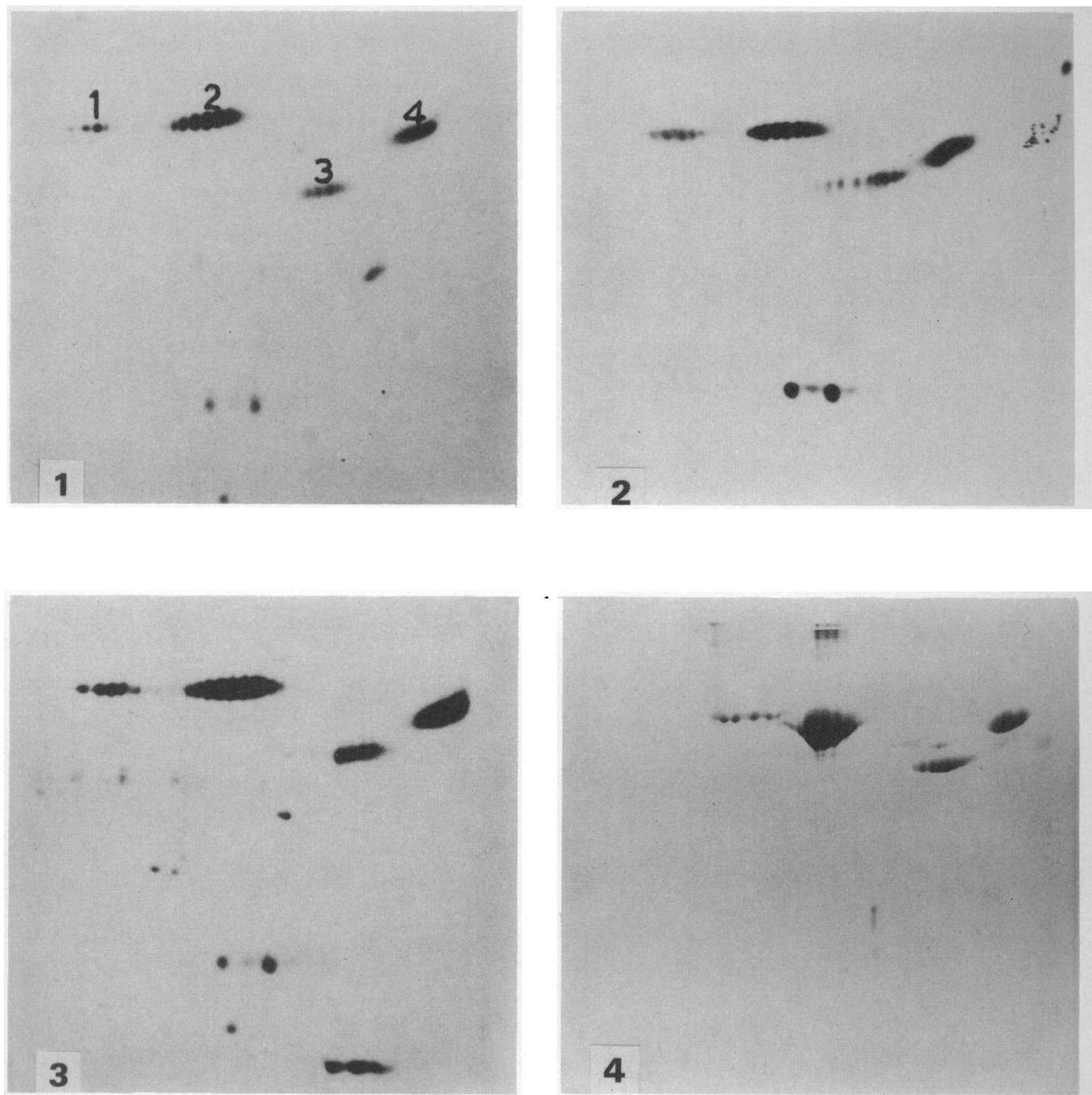

Fig. 1. Fluorograph of a two-dimensional polyacrylamide electrophoretic gel ( $10 \%$ acrylamide) of polypeptides released into the incubation medium by confluent attached cell cultures established from dissociated sheep blastocysts. Polypeptides labelled 1-4 have been tentatively identified as: 1, transferrin; 2, $\alpha$-fetoprotein; 3, $\alpha_{1}$-antitrypsin; and 4, $\alpha$-antichymotrypsin.

Fig. 2. Fluorography of a two-dimensional polyacrylamide electrophoretic gel $(10 \%$ acrylamide) of polypeptides released into the incubation medium by floating fluid-filled spheres established from dissociated sheep blastocysts.

Fig. 3. Fluorograph of a two-dimensional polyacrylamide electrophoretic gel ( $10 \%$ acrylamide) of polypeptides released into the incubation medium by floating cells, which failed to attach to the plastic substratum, of dissociated sheep blastocysts.

Fig. 4. Coomassie blue-stained two-dimensional polyacrylamide electrophoretic gel $(10 \%$ acrylamide) of polypeptides from serum of a fetal sheep at Day 140 of gestation. 


\section{PLATE 2}
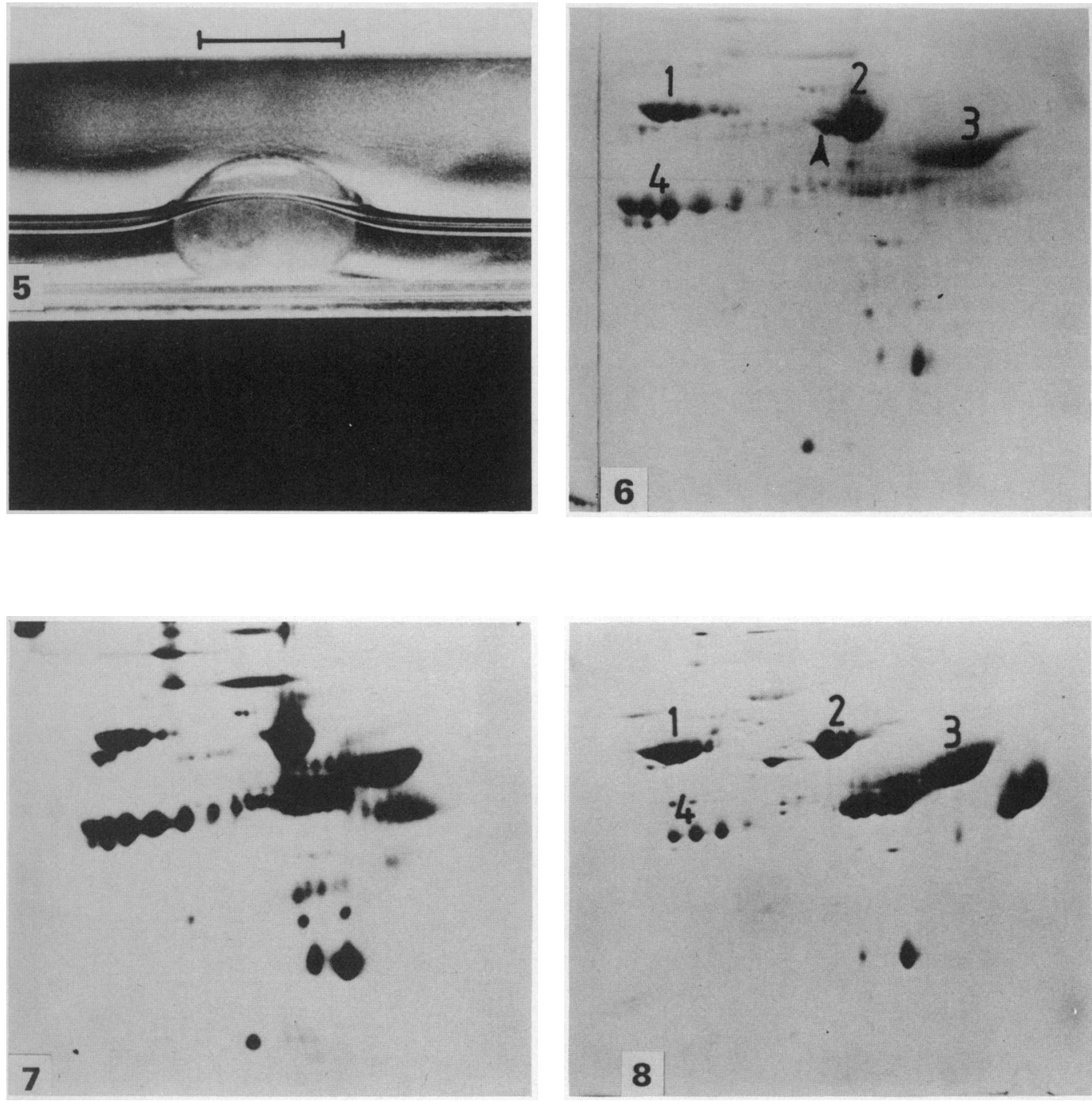

Fig. 5. Photograph of a fluid-filled sphere established from dissociated pig blastocysts after about 2 weeks in culture. The line above sphere represents $1 \mathrm{~cm}$.

Fig. 6. Coomassie blue-stained polyacrylamide electrophoretic gel (10\% acrylamide) of polypeptides released into culture medium by fluid-filled spheres established from dissociated pig blastocysts.

Fig. 7. Fluorograph of the gel shown in Fig. 6.

Fig. 8. Coomassie blue-stained polyacrylamide electrophoretic gel $(10 \% \mathrm{w} / \mathrm{v}$ acrylamide $)$ of polypeptides from the serum of a fetal pig at Day 60 of gestation. 
date, similar in-vitro observations have not been reported for blastocysts taken from the large domestic species.

When analysed by two-dimensional PAGE, confluent cell layers, floating fluid-filled spheres, and cells that failed to attach during the initial plating of dispersed sheep blastocysts cells, all released as major products polypeptides with electrophoretic mobilities and molecular weights identical to those of fetal plasma proteins. Only the cells that failed to attach produced ovine trophoblast protein 1, the major polypeptide produced by the trophectoderm cells of the sheep conceptus between Days 13 and 21 of pregnancy (Godkin et al., 1982a, 1984). One explanation for this observation may be that the trophoblast cells did not proliferate well under the culture conditions employed and the cultures were rapidly dominated by other more successful cell types. This explanation is supported by the fact that the large, thin, flat cells, which resembled trophectoderm morphologically, stopped dividing 2-4 days after plating and were overgrown by small, compact cells. The fact that some of the dissociated sheep cells (those that did not attach) were able to synthesize trophoblast-specific protein may be of significance. Relatively pure populations of trophoblast cells, dissected out from intact blastocysts, could perhaps be established under proper culture conditions and specific trophoblast products could be harvested from these cultures.

The major polypeptides released by fluid-filled spheres and confluent cell cultures derived from pig blastocysts had identical electrophoretic characteristics to fetal plasma proteins of pigs. The spheres and confluent cell cultures did not synthesize the proteins characteristically released into the incubation medium by whole Day-14-16 pig conceptuses in culture (Godkin et al., 1982b). Unfortunately, free-floating dissociated pig cells were not submitted to two-dimensional PAGE analysis.

Others have observed the formation of 'vesicles' by embryonic cells and tissues in culture (Gardner, 1972; Bell \& Sherman, 1973; Fiser \& McPherson, 1976; Heyman, Camous, Fevre, Meziou \& Martal, 1984). Gardner (1972) microsurgically separated the inner cell mass from trophectoderm of mouse blastocysts and observed that trophectoderm tissue reformed spherical structures which he named "trophoblastic vesicles". Similarly, Heyman et al. (1984) observed the formation of vesicles from dissected sheep and cow conceptuses. The large spheres observed in our studies differ from those mentioned above in that they did not form from pieces of dissected trophoblast but developed from dissociated cells from whole conceptuses. The structures formed were identifiable microscopically within $4 \mathrm{~h}$ of seeding and developed into macroscopic structures approaching $1 \mathrm{~cm}$ in diameter after 1-2 weeks. Although the cell type(s) composing the spheres could not be accurately identified (due to lack of specific cell markers such as monoclonal antibodies to specific cell-surface antigens) results of the biochemical analysis indicated that the cells composing the spheres were probably not primarily derived from trophectoderm.

The yolk sac has been implicated in the production of fetal plasma proteins in several species (for review of neonatal and fetal plasma protein see Gitlin \& Gitlin, 1975). Cultures of the cells of mouse inner cell masses form hollow vesicles which contain cells with biochemical properties similar to those of the mid-gestational yolk sac (Bell \& Sherman, 1973). A system of capillary-like structures was observed in our spheres derived from pig blastocysts and resembled the capillaries observed in yolk sac membranes from Day-15-18 pig conceptuses. Based on our biochemical studies (protein analysis) it is likely that the protein secreting cells of the cultures and fluid-filled spheres were derived largely from an embryonic cell type such as yolk sac which is programmed to produce plasma protein. This suggestion is supported by the fact that the yolk sacs of sheep and pig conceptuses are in a rapid stage of growth at the period of development (Days 14-16) when the cultures were begun. In addition, we have previously dissected out extraembryonic membranes of sheep and pig conceptuses and placed them in short-term organ culture (Godkin et al., 1982a, b; unpublished): the results demonstrated that yolk sac membranes produce plasma-like proteins while trophoblast produces proteins characteristic of whole blastocyst cultures.

This work was supported by grant HD-10436 from the National Institute of Health 


\section{References}

Aggarwal, B.B., Farmer, S. W., Papkoff, H., Stewart, F. \& Allen, W.R. (1980) Purification and characterization of the gonadotropin secreted by cultured horse trophoblast cells. Endocrinology 106, 1755-1759.

Alieh, W.R. \& Moor, R.M. (1972) The origin of the equine endometrial cups. I. Production of PMSG by fetal trophoblast cells. J. Reprod. Fert. 29, 313-316.

Anderson, L. \& Anderson, N.G. (1977) High resolution two-dimensional electrophoresis of human plasma proteins. Proc. natn. Acad. Sci. U.S.A. 74, 5421-5425.

Bastia, S.M.M., Bazer, F.W. \& Roberts, R.M. (1979) The secretion of a uterine specific purple phosphatase by cultured explants of porcine endometrium. Dependency upon the state of pregnancy of the donor animal. Biol. Reprod. 20, 431-441.

Beil, K.E. \& Sherman, M.I. (1973) Enzyme markers of mouse yolk sac differentiation. Devl Biol. 33, 38. 47 .

Blafidau, R.J. (1971) Culture of guinea pig blastocyst. In Biology of the Blastocyst, pp. 59-70. Ed. R. J. Blandau. University of Chicago Press, Chicago.

Chamberlain, J.P. (1979) Fluorographic detection of radioactivity in polyacrylamide gels with the water soluble fluor sodium salicylate. Analyt. Biochem. 98, 132-135.

Cole, R.J. \& Paul, J. (1965) Properties of cultured preimplantation mouse and rabbit embryos and cell strains derived from them. In Preimplantation Stages of Pregnancy, pp. 82-122. Eds G. E. Wolstenholme \& M. O'Connor. Little, Brown \& Co., Boston.

Edwards, R.G. (1964) Cleavage of one- and two-celled rabbit eggs in vitro after removal of the zona pellucida. J. Reprod. Fert. 7, 413-415.

Fiser, P.S. \& Macpherson, J.W. (1976) Development of embryonic structures from isolated mouse blastofheres. Can. J. Anim. Sci. 56, 33-36.

Gardner, R.L. (1972) An investigation of inner cell mass and trophoblast tissues following their isolation from the mouse blastocyst. J. Embryol. exp. Morph. 28, 279-312.

Gitlin, D. \& Gitlin, J.D. (1975) Fetal and neonatal development of human plasma proteins. In The Plasma Proteins, Structure, Function and Genetic Control, Vol. 2, pp. 263-321. Ed. F. W. Putnam. Academic Press, New York.

Godkin, J.D., Bazer, F.W., Moffatt, J., Sessions, F. \& Roberts, R.M. (1982a) Purification and properties of a major low molecular weight protein released by the trophoblast of sheep blastocysts at Day 13-21. J. Reprod. Fert. 65, 141-150.

Godkin, J.D., Bazer, F.W., Geisert, R.D., Lewis, G.S. \& Roberts, R.M. (1982b) Synthesis and release of polypeptides by pig conceptuses during the period of blastocyst expansion and attachment. Biol. Reprod. 27, 977-987.

Godkin, J.D., Bazer, F.W. \& Roberts, R.M. (1984) Ovine trophoblast protein 1 , an early secreted blastocyst protein, binds specifically to uterine endometrium and affects protein synthesis. Endocrinology 114, 120131.
Gwatkin, R.B.L. (1966) Defined media and development of mammalian eggs in vitro. Ann. N.Y. Acad. Sci. 139, 79-90.

Heyman, Y., Camous, S., Fevre, J., Meziou, W. \& Martal, J. (1984) Maintenance of the corpus luteum after uterine transfer of trophoblastic vesicles to cyclic cows and ewes. J. Reprod. Fert. 70, 533-540.

Hogan, B. \& Tilly, R. (1977) In-vitro culture and differentiation of normal mouse blastocysts. Nature, Lond. 265, 626-629.

Horst, N.N. \& Roberts, R.M. (1979) Analysis of polypeptide turnover rates in Chinese hamster ovary cell plasma membranes using two-dimensional electrophoresis. J. biol. Chem. 254, 5000-5007.

Hsu, Y.C. (1971) Post-blastocyst differentiation in vitro. Nature, Lond. 231, 100-102.

Hsu, Y.C. (1972) Differentiation in vitro of mouse embryos beyond the implantation stage. Nature, Lond. 239, 200-202.

Hsu, Y.C. (1973) Differentiation in vitro of mouse embryos to the stage of early somite. Devl Biol. 33, $403-411$.

Khodr, G.S. \& Siler-Khodr, T.M. (1980) Placental luteinizing hormone-releasing factor and its synthesis. Science, N.Y. 207, 315-317.

Laskey, R.A. \& Mills, A.D. (1975) Quantitative film detection of ${ }^{3} \mathrm{H}$ and ${ }^{14} \mathrm{C}$ in polyacrylamide gels by fluorography. Eur. J. Biochem. 252, 6510-6515.

Masters, R.A., Roberts, R.M., Lewis, G.S., Thatcher, W.W., Bazer, F.W. \& Godkin, J.D. (1983) High molecular weight glycoproteins released by expanding pre-attachment sheep, pig and cow blastocysts in culture. J. Reprod. Fert. 66, 571-583.

Mintz, B. (1964) Formation of genetically mosaic mouse embryos, and early development of "lethal (t12/t12) normal" mosaics. J. exp. Zool. 157, 273-292.

O'Farrell, P.H. (1975) High resolution two dimensional electrophoresis of protein. J. biol. Chem. 250, 40074021.

Owens, N.O. \& Blandau, R.J. (1971) Proteolytic activity of rat and guinea pig blastocyst in vitro. In Biology of the Blastocyst, pp. 207-224. Ed. R. J. Blandau. University of Chicago Press, Chicago.

Patten, B.M. (1931) The early development of the body form and establishment of the organ system. In Embryology of the Pig, pp. 37-59. Ed. B. M. Patten. Maple Press Co., York.

Ruddon, R.W., Hartle, R.J., Peters, B.P., Anderson, C., Huot, R.I. \& Stromberg, K. (1981) Biosynthesis and secretion of chorionic gondotropin subunits by organ culture of first trimester human placenta. J. biol. Chem. 256, 11389-11392.

Shaffer, S.J. \& Wright, R.W., Jr (1978) Attachment and trophoblastic outgrowth of swine blastocysts in vitro. J. Anim. Sci. 46, 1712-1717.

Sherman, M.I. (1975) Long term culture of cells derived from mouse blastocysts. Differentiation 3, 51-67.

Stevens, D.H., Mallon, A. \& Nathanielsz, P.W. (1980) Sheep trophoblast in monolayer cell culture. Placenta 1, 209-221. 